\title{
Evaluation of Balance and Walk and their Relationship to the Occurrence of Falls in Elderly
}

Lia Raquel de Carvalho Viana1, Katia Nêyla de Freitas Macedo Costa², Tatiana Ferreira da Costa ${ }^{3}$, Thayris Mariano de Medeiros ${ }^{4}$, Raquel Janyne de Lima ${ }^{4}$, Thaise Alves Bezerra ${ }^{5}$, Laudicea da Silva Sales ${ }^{6}$, Kaisy Pereira Martins ${ }^{3}$, Stella Costa Valdevino ${ }^{3}$, Gerlania Rodrigues Salviano1, Maria Cristina Lins Oliveira Frazão1,Silmery da Silva Brito Costa7, Keylla Talitha Fernandes Barbosa ${ }^{3}$, Kamila Nethielly Souza Leite ${ }^{7}$

\section{Abstract}

Introduction: Falls are a geriatric syndrome, and among the risk factors there are the balance and walking problems, becoming necessary the evaluation of these parameters for targeting care to prevent falls.

Objective: Evaluating the balance and the walk as predictors of the risk of falls in the elderly.

Methods: A cross-sectional, exploratory and quantitative study conducted with 130 elderly. There were evaluated the balance and the walking through the Tinetti Scale and the data were analyzed using statistical software. The study was approved by the Ethics Committee under the advice number 963.157.

Results: $60 \%$ of the sample presented an average risk for falls, and the average test of balance and walking was lower among older people with a history of falls.

Conclusion: It is important that nurses perform multidimensional geriatric assessment in order to detect changes and minimize the risk of falls in the elderly.

Keywords

Elderly; Accidental Falls; Risk Factors; Health Services for the Aged; Walking;

Postural Balance.
1 Nursing Graduation Student, Federal University of Paraiba. Joao Pessoa, Paraiba, Brazil.

2 Doctorate in Nursing, Teaching at the Nursing Postgraduate Program, Federal University of Paraiba. Joao Pessoa, Paraiba, Brazil.

3 Doctoral Student at the Nursing Postgraduate Program, Federal University of Paraiba. Joao Pessoa, Paraiba, Brazil.

4 Master's Student at the Nursing Postgraduate Program, Federal University of Paraiba. Joao Pessoa, Paraiba, Brazil.

5 Master of Public Health, State University of Paraiba. Campina Grande, Paraiba, Brazil.

6 Assistant Nurse, Comprehensive Care Center for Elderly Health. Joao Pessoa, Paraiba, Brazil.

7 Masterin Nursing, Federal University of Paraiba. Joao Pessoa, Paraiba, Brazil.

Contact information:

Thayris Mariano de Medeiros Programa de Pós-graduação em Enfermagem.

Address: Universidade Federal da Paraíba. João Pessoa, Paraíba, Brazil. Tel./Fax: 0055(83)98834-6604.

झ thayris_mariano@hotmail.com 


\section{Introduction}

As the elderly population grows, there is an increase in the prevalence of factors that expose the elderly to a decline in quality of life [1]. Fall is considered one of these factors and their causes can be intrinsic and / or extrinsic [2]. Intrinsic factors include the physiological changes of aging (muscle weakness, balance reduction, cognitive impairment, etc.) [1] or pathological conditions, and extrinsic factors come from the environment in which the elderly is inserted (poor lighting, loose rugs, high steps, slippery floors and others) [2].

With regard to mechanisms of injury in the elderly, in decreasing order of prevalence, the fall event occupies the first, being the most common (40\%), followed by traffic accidents (28\%) and pedestrians (10\%). Data indicate that 28 to 35\% of people over the age of 65 fall at least once during the year worldwide [3]. Thus, the fall is considered a geriatric syndrome [4] and is configured as a public health problem due to high incidence, morbidity and mortality and the high socioeconomic costs resulting from injuries [5].

Changes in body balance and walking are mentioned in the literature as two of the main risk factors for falls in the elderly [4]. The aging process promotes naturally several changes in the individual's body and identifies common parameters of reduced muscle mass and bone density that weaken the individual engine component, weakening it [3]. In this context, changes in work capacity, posture and adaptability to the environment [6], which when added to reduce the vestibular sensitivity and proprioception contribute to the occurrence of imbalances $[6,7]$, predisposing the elderly to fall event [3].

Falls in the elderly promote increased hospitalizations and/or institutionalization, social isolation, increased susceptibility to diseases, predisposing the fear of falling again and the occurrence of fractures and other complications or even death [1]. The physical consequences can pose constraints in per- forming activities of daily living, which added to the psychological and social consequences that the fall brings to the elderly, ending in the loss of independence and autonomy of the individual. [6]

Based on this reality, nursing must identify the needs and risks of the elderly, directing care for the risk factors of the most significant falls [8]. In primary care, the nurse has fast multidimensional geriatric assessment that it is a synthesis of multidimensional evaluation, and used to identify health problems determinants of functional decline in the elderly, such as the risk of falls. 13 areas are assessed, including aspects considered risk factors for falls, such as urinary incontinence, vision, cognition, direction, functions of the lower limbs, among others. While these areas are affected, the nurse must perform a second more detailed assessment and thus, prepare its plan of care targeting the elderly [9].

Thus, the objective of this research was to evaluating balance and walking and their relation to the occurrence of falls in elderly people attended at a Center of Integral Attention for Elderly Care.

\section{Methods}

It is a cross-sectional and exploratory study of a quantitative approach. The research scenario was a Comprehensive Care Center for Elderly Care, located in Joao Pessoa, Brazil. The center is a medium complexity unit which provides individual and group outpatient services in multiple specialties, getting older patients who are referred from all Family Health Units of the municipality. However, the aforementioned health service tends to play the role of the primary assistance when necessary, in an attempt to fulfill the needs in demand.

The population studied consisted of elderly assisted by spontaneous demand, in that health service. The sample was calculated by a statistical calculation, considering the number of visits during the last 3 months of 2014 (October, November and December), a total of 16.495 calls. In order to estimate 
the prevalence of risk of falls in this population it was initially conducted a pilot survey in which 20 elderly participated, of which 19 (proportion 95\% or 0.95 ) presented medium to high risk of falls when assessed by Tinetti'sRating Scale of Balance and Walking [9]. The sample size calculation was performed based on a 5\% margin of error (Error $=0.05)$ with a level of reliability of $95 \%(\alpha=0.05$, which provides $Z 0,05 / 2=1.96$ ) and considering the proportion equivalent to $95 \%$, providing a sample of 73 elderly. However, considering the availability and time for data collection, the final sample included 130 elderly. Participated in the survey, elderly, sixty years old or so, that after clarification of the objectives and the operational steps, agreed to participate in the collection.

Data collection was conducted from February to April 2015. The same happened upon approach of the elderly in the corridors and waiting rooms of that health service in times before or after the consultations. Analysis of clinical and demographic profile was conducted through interviews using semistructured instrument in which there were identified sociodemographic data and questions regarding the history of previous falls of the patient. The assessment of balance and walking was performed by Tinneti'sAssessment Scale of Balance and Walking [9]. Such an instrument it is a Mary Tinetti protocol proposed in 1986, which was translated and validated in Brazil in 2003 by Gomes [10], getting the name of POMA-Brazil [11]. However, they do not appear in the literature descriptions about the cutting scores that represent risk of falls to POMABrazil [12] and therefore the scores currently used refer to Tinetti's Scale [9].

The Tinetti's Scale consists of 16 items, in which 9 assess the balance and 7 assess the walking. Regarding the balance, there are evaluated the following: sitting balance, balance to rise, many attempts to stand, balance in the first 5 seconds after standing, balance standing test of three fields (the examiner gently pushes the outside of the elderly person should not unbalance), balance with closed eyes, balance rotating $360^{\circ}$ and sitting balance again after turn. With regard towalking, there are evaluated: onset of walking (if there is hesitancy), length and height of the steps, symmetry of the steps, continuity of steps, direction of travel, trunk (if there is balance, bending and opening the arms) and the distance ankles [9].

This scale has been widely used since it detects changes in locomotion and mobility, diagnoses and quantifies the severity of impairment and predicts the risk of the individual drops [13]. In addition, it does not require sophisticated equipment for its application and has high level reliability in detecting changes in walking and balance. A score above 24 points predicts low risk of falling, between 19 and 24 points a moderate risk of falling, and below 19 points, high risk of falling [12].

After collection, initially, data were compiled and stored in a Microsoft Office Excel version 2013 spreadsheet and analyzed with the help of Statistical Package for Social Sciences (SPSS) version 20.0. Completed typing and checking the consistency of data, began the descriptive and exploratory analysis of the variables, calculating distribution measures such as absolute and relative frequencies and measures of central tendency, such as arithmetic mean and standard deviation (SD). With regard to the comparison of the average balance and walking through Tinneti'sRating Scale between groups, bivariate analyzes were performed using the T-Student test for independent samples, considering the homogeneity of variances, previously tested by the Kolmogorov-Sminorv Test. In order to identify associations between the data, the Fisher's exact test was used as statistical tool, considering statistically significant association when $\mathrm{P}$-value $<0.05$. The results were expressed in tables.

During the research, all legal and ethical issues concerning studies performed with human beings were fulfilled, recommended by Resolution 466/12 of the National Health Council. [14] The project was 
submitted to the Research Ethics Committee of the Health Sciences Center of the Federal University of Paraiba (CCS-UFPB), CAAE: 41019315.3.0000.5188, for which was approved by Opinion No 963,157. It should be noted that throughout the process of research, especially for the time of data collection, it has adhered to the principle of autonomy, privacy and dignity, by requesting participation in the study through the Term of Consent.

\section{Results}

The study included a total of 130 elderly, 98 (75.4\%) women and $32(24.6 \%)$ men, with a predominance of the age group between 70-79 years old (51.5\%). Regarding marital status, 69 (53.1\%) were married. Regarding schooling, 50 (38.5\%) had primary education and 37 (28.5\%) high school. Most participants had income equivalent to 1-3 minimum wages $(90.8 \%)$ and $83.1 \%$ were retired.

Regarding the distribution of the elderly in relation to falls and characteristics of these, there was a high number of individuals who have suffered falls, making a total of $93(71.5 \%)$, of which more than half $(50.6 \%)$ suffered from 1 to 3 episodes of fall, most often attended by (an) other person (s) (68.8\%), and 47 (50.5\%) could not stand alone after the event. With regard to activities carried out at the time of the falls, 28 (30.1\%) reported that they usually walked in the street, 23 (24.7\%) practiced walking and 18 (19.4\%) performed domestic activities. As the post-change falls, 25 elderly (28.1\%) had these, the most prevalent physical changes in upper and lower limbs. Fear of falling was reported by $15(11.5 \%)$.

The following tables show the distribution of the elderly in relation to falls risk classification according to Tinneti's Scale, as well as correlations between the risk of falls and the occurrence of the same history and also its characteristics, respectively.

According to Table 1, of the 130 participants, 78 $(60 \%)$ had high risk of falls and 45 (34.6\%) had high risk.
Table 1. Distribution of elderly people in relation to the risk of falls. Joao Pessoa, Paraiba, Brazil, $2015(n=130)$.

\begin{tabular}{|l|c|c|}
\hline \multicolumn{1}{|c|}{ Classification } & $\mathbf{n}$ & $\%$ \\
\hline High risk & 45 & 34.6 \\
\hline Mediumrisk & 78 & 60.0 \\
\hline Lowrisk & 07 & 5.4 \\
\hline
\end{tabular}

Table 2. Comparison of the arithmetic means obtained from Tinneti's Scale of assessment of walking and balance, according to the occurrence of falls among the elderly. Joao Pessoa, Paraiba, Brazil, 2015 ( $n=130)$.

\begin{tabular}{|c|c|c|c|c|c|}
\hline \multirow{3}{*}{ Variable } & \multicolumn{4}{|c|}{ Falls } & \multirow{3}{*}{ P-value ${ }^{a}$} \\
\hline & Yes & \multirow[b]{2}{*}{ SD } & No & \multirow[b]{2}{*}{ SD } & \\
\hline & $\begin{array}{c}\text { Arithmetic } \\
\text { mean }\end{array}$ & & $\begin{array}{c}\text { Arithmetic } \\
\text { mean }\end{array}$ & & \\
\hline $\begin{array}{l}\text { Total } \\
\text { Score }\end{array}$ & 19.55 & 3.58 & 21.43 & 3.07 & 0.006 \\
\hline $\begin{array}{l}\text { Balance } \\
\text { Score }\end{array}$ & 11.67 & 1.81 & 12.59 & 1.73 & 0.005 \\
\hline \multirow[t]{2}{*}{$\begin{array}{l}\text { Walking } \\
\text { Score }\end{array}$} & 7.73 & 2.14 & 8.86 & 1.75 & 0.009 \\
\hline & & & & \multicolumn{2}{|c|}{ a: Test T-Student } \\
\hline
\end{tabular}

Table 3. Correlation between the risk for falls and the characteristics of earlier events. Joao Pessoa, Paraiba, Brazil, 2015 ( $n=130)$.

\begin{tabular}{|c|c|c|c|c|c|}
\hline \multirow{3}{*}{ Variable } & \multicolumn{4}{|c|}{ Risk } & \multirow{3}{*}{ P-value ${ }^{a}$} \\
\hline & \multicolumn{2}{|c|}{ Without risk } & \multicolumn{2}{|c|}{ With risk } & \\
\hline & $n$ & $\%$ & $n$ & $\%$ & \\
\hline \multicolumn{6}{|c|}{ Previous falls } \\
\hline Yes & 04 & 57.1 & 89 & 72.4 & \multirow{2}{*}{0.316} \\
\hline No & 03 & 42.9 & 34 & 27.6 & \\
\hline \multicolumn{6}{|c|}{ Quantity of falls } \\
\hline $1-3$ & 02 & 50.0 & 45 & 50.6 & \multirow{2}{*}{0.683} \\
\hline 4 or more & 02 & 50.0 & 44 & 49.4 & \\
\hline \multicolumn{6}{|c|}{ Occurrence of post-falls changes } \\
\hline Yes & 00 & - & 25 & 28.1 & \multirow{2}{*}{0.279} \\
\hline No & 04 & 100 & 64 & 71.9 & \\
\hline \multicolumn{6}{|c|}{ a: Fisher's exact test } \\
\hline
\end{tabular}


With regard to balance and walking, variables that make up the scale, the present study found that there was a prevalence of changes in some of these. Regarding the balance, 106 elderly $(81.5 \%)$ used their arms to sit, and when standing, 88 (67.7\%) balanced with their feet apart, $73(56.2 \%)$ used their arms as support for up, 72 (55.4\%) presented themselves unbalanced eyes closed and testing of the 3 courses, 71 (54.6\%) seized or rocked. Regarding the walking variables, $125(96.2 \%)$ had away from ankle while running and 115 (88.5\%) beyond the supporting foot. In addition, 82 (63.1\%) had mild or moderate shift in direction, 76 (60\%) flexed their knees and opened their arms and 66 (50.8\%) did not completely lifted off the ground.

Regarding the final arithmetical mean obtained with the Tinneti's Scale, it was 20.08 \pm 3.53 ; in the balancing test, the mean obtained was $11.93 \pm 1.83$, and the one obtained in the evaluation of walking was $8.05 \pm 2.10$.

Comparing the arithmetical means obtained through the Assessment of Balance and Walking through Tinneti's Scale, according to the occurrence of falls in the study population, it was found that there are differences between those groups who fell and those who did not experience such an event.

According to Table 2, it was found that the arithmetic mean obtained in Tinneti's Scale is higher among the elderly who did not fall $(21.43 \pm 3.07)$ compared with the elderly who fell $(19.55 \pm 3.58)$, as well as the isolated scores of balance and walking, thus presenting statistical significance.

Table 3 shows the association between the risk of falls and the characteristics of past falls in the elderly. In this table, it was used the classification with and without risk, according to which elderly without risk are the ones who presented low risk of falls and elderly with risk presented medium or high risk of falling.

Of the elderly with risk of falls (medium and high risk), 89 (72.4\%) had already fallen before. Regar- ding the number of falls suffered, of the elderly who presented risk, just over half of them (50.6\%) suffered 1-3 episodes of falls and the remainder (49.4\%) suffered 4 or more falls. However, these associations were not statistically significant.

Regarding the post-fall changes, of 89 who were at risk, 64 (71.9\%) reported no change, whether physical or psychological. Thus, it was not observed in this study that post falls changes establish a significant relationship with the risk of falls.

\section{Discussion}

Most of the sample performed in this study was composed of women (75.4\%). Authors explain that there is a process of "feminization" of old age, showing that the female population grows faster than the male, probably due to a higher mortality rate in males and increased life expectancy in the female population [15]. In addition, elderly tend to seek more frequent health care by establishing a bond with them. [16]

It was found in the elderly assessed high incidence of falls (71.5\%). The degenerative aging process promotes morphological and functional changes making the individual more susceptible to diseases [17], with the fall event between them, thus providing a striking reality in old age, being demonstrated through studies $[18,19]$. A national populationbased study found an incidence of 37.5\% corresponding falls in the elderly [4].

More than half of patients included in this study suffered recurrent falls, agreeing with other results found in literature $[20,21]$. The presence of a history of falls is strongly associated with the occurrence of further declines, evidencing scientifically [22]. In this regard, some authors state that more than twothirds of seniors who fall will fall again in the subsequent 6 months [23], and one explanation is that falls can lead to a vicious cycle in which the elderly which reduces its functionality due to a previous decline becomes more susceptible to undergoing further declines [3]. 
When questioned about the activities at the time of the falls, the most cited corresponded to walking, hiking and carrying out household tasks, corroborating the findings of other authors [19, 24, 25]. Often falls occur in the home environment $[19,25]$ and on the street, as identified in research [1, 24, 25]. The home environment is very conducive to the occurrence of falls, which may cause tripping on shoes, furniture, clothing, carpets, and slips into the kitchen floors and bathrooms, for example, especially when the elderly performs cleanup tasks [26]. However, the decrease in the home it is a relatively simple event to be avoided, whereas reorganization preventive measures can be adopted [20]. On the street environment, it is considered a risk factor for falls therefore has uneven sidewalks, favoring stumbling [27]. The same authors found that up on buses (11.4\%) and fast pedestrian lighthouse (20\%) also present risks. In this context, it is essential that there is an environmental adaptation at home where the elderly spends most of their time to promote a reorganization and furniture settings and comfortable, for example [27]. Nursing professionals as they lay closer to the patient, performing home visits, holds the potential to identify risks in the homes of the elderly, and contribute to this reorganization, through guidelines. On the streets, it is government's responsibility to make them safer and passable for the elderly considering their needs. [27]

Regarding the physical changes after falls, few elderly mentions about. However, it is known that the drops can cause a variety of physical complications in old age, so that fractures, bruises, lacerations and various injuries are among the most prevalent, not to mention the risk of death depending on the complexity of the event [28].

Fear of falling was reported by small part of the sample. Also to fall, afraid to suffer it is a multidimensional phenomenon behaving physical, psychological, social and functional [29]. With regard to this, a survey of 1,705 elderly people found that 322 suffered fall in the last year, and more than half afraid of falling again. [24] This is a matter of concern, since fear can discourage the individual in performing daily activities due to loss of confidence, thereby enhancing immobility [30] and the limitations imposed by the complications of the fall, thus taking the elderly to dependence [1] and the increased possibility of suffering further declines.

With regard to assessing the risk of falls through balance and gait of the elderly, the values found show that almost the entire sample showed medium and high risk. Approximate findings were found in other studies that diagnosed high risk of falling into $64.7 \%$ [11] and 59.7\% [31] of the investigated.

The aging as a natural process makes possible the existence of several factors that tend to increase the fall, such as: sensorimotor changes, muscle weakness, osteoporosis, reduced body flexibility, polypharmacy, visual impairment, among others. [9] The fall means a risk potential for the elderly, it can cause complications such as underactive, depression, increased morbidity, weakness and fear, inability to maintain balance, giving rise beyond a physical degeneration board also psychological because the individual tends reduce their social participation and interactivity. [32] In this perspective, the fall brings a reduction of well-being and quality of life in old age [33]. In order to minimize the damage resulting from the aging process, the nurse must assist the elderly in order to prioritize the realization of multidimensional evaluation recommended by the Ministry of Health, which covers the tracking of various sizes, particularly about the risk of falls in elderly [9].

Among the parameters evaluated with the Tinetti's Scale, walking was more impaired compared to the balance. At older ages, individuals tend to show changes in walking, constituting senile walking, which favors the risk of falling [7]. This type of walking is characterized as slowed, dragged and accompanied by a "waddle" [34]. In research with older people in Australia, authors found impaired gait parameters, which are more likely to drop indi- 
viduals. In addition, those who have fallen have had greater difficulties to start walking. [18]

Regarding the variables that make up the Tinetti's Scale, when the equilibrium parameters evaluated, most seniors showed the following changes: use of arms as support for sitting and standing, feet apart when standing, and imbalance with closed eyes and during the testing of three fields. The walking of execution, most participants showed deviation in direction and did not lift their feet off the ground, held deep knee bends or open arms, and kept their distance ankle and exceeded the footrest. This latter aspect may predispose to destabilization since there is an increase in step.

Studies corroborate this research as presented similar results regarding the variables evaluated [11, 35]. Authors found that more than half of the participants needed to support the arms to lift and as regards distance ankles, 58.8\% had abnormal measurements [11]. Other data show that almost all the elderly needed support arms for sitting and standing, and walking, 75\% exceeded the foot rest, $65 \%$ had deviation in direction, and more than half remained distant ankles, and 45\% performed knee flexion or open arms. [35]

During the natural process of aging, individuals tend to show a decline in the activities that require the use of the visual system, buccal, somatosensory and central nervous system, which when affected, promote body imbalance [33]. Faced with this problem, the elderly tend to adopt adaptation measures, such as support arms to lift and / or sit in the search for balance. [35]

In elderly, walking may be affected due to the appearance of chronic degenerative disease, postural hypotension, and orthopedic surgery, among other reasons [36]. While walking, the elderly try to adapt their musculoskeletal system in order to generate body stability for their locomotion [37]. To this end, the individual reduces the speed of walking, lentifying steps and shuffling when walking, but increasing the support base [19]. Failure to properly lift the foot can cause the occurrence of stumbling [36]. Moreover, as compensatory attitudes to the imbalance, there are open arms and advance the center of gravity of the body [9]. Generally, the elderly presents shorter and more frequent steps [36], but this aspect differed from that found in this study.

When established an association between the arithmetic mean obtained with the Tinneti's Scale and the occurrence of falls, the results revealed that the arithmetic mean is higher among the elderly who did not fall compared with the mean of the ones who fell, which means that elderly people who fell had worse performance of balance and walking, compared to those who did not fall, thereby establishing a statistically significant difference. Other authors [8] also demonstrated that problems such as proprioceptive deficits, postural and balance and walking proved to be higher in the elderly who have suffered falls. These results reinforce the literature about this subject, which is quite clear in stating that the balance and walking changes have a direct relationship with the occurrence of falls in the elderly, constituting a risk factor $[37,8]$.

In a second association between the risk and the occurrence and recurrence of falls, most seniors with risk (medium and high) presented history of falls, especially recurring. These, in turn, are part of the history of elderly people with higher risk. The applicant drop may represent an important new risk factor for falls, since this may impair the activity of walking [38]. This is because the elderly who have fallen have more difficulty maintaining static control body compared to those who did not fall [34]. In addition, authors state that individuals who have already fallen tend to adapt their shape to walk, featuring a "cautious walking" [29], a factor that may contribute to the occurrence of further declines.

Inserted in this context, nursing should work together with the other team members in preventing falls in the elderly, especially in primary care that is one of the entrance doors of health care, spa- 
ce where the nurse plays an essential role in the health care process the elderly population through the multidimensional evaluation [39]. With regard to balance and walking parameters, there must be a trace of them, in search of what may generate or be generating frames of instability and other amendments, and consequently, risk of falls [37]. The identification of changes in these parameters is important as it gives the professional the development of focused care plans not only prevention, but also the protection of health and rehabilitation, where appropriate.

On the other hand, it is necessary that the elderly also have co-responsibility with regard to prevention, investing in the practice of self-care. However, much of the elderly population still has difficulty to become aware and recognize the risk factors for falls and do not report when they consult, with prevention neglected in a way, until the fall occasion a significant impact and the elderly decide the case. [40]

The denial of some of the elderly in participating willingly or due to the timing of the consultation on health services was the limitation of this research.

\section{Conclusion}

It showed that the majority of the sample presented medium and high risk of falling, indicating how much the assessed elderly are exposed to the risk of falls due to the balance and walking changes. It was observed that the arithmetic mean in the assessment of balance and walking is lower among the elderly who have suffered falls compared to the mean of the elderly who did not fall, representing a statistically significant difference. In addition, concerning the elderly presenting risk of falls (medium and high risk), there was prevalence of those who have suffered falls, although this association was not statistically significant.

It is hoped that this study can contribute to expand the relevance of investigating the risk factors for falls and thus to encourage a look towards the protection of the elderly's health.

It is important that nurses perform initially a multidimensional evaluation, in order to develop care targeted to postpone the deterioration of parameters in the elderly, such as balance and gait, so that they will not interfere with the risk of falls in the elderly. In this context, it is essential that the multidisciplinary team knows the view of the elderly population, identifying their real needs and, above all, being able to recognize the fall as a geriatric syndrome and, in the face of this issue, to intervene by means of preventive actions, contributing, thereby, to better living conditions and to a healthy aging.

\section{Recommendations}

It is strongly recommended that further research concerning the assessment of the balance and gait, and their relation to the occurrence of falls, should be undertaken, in different scenarios, in the search for more subsidies regarding the relation between these parameters, thereby reinforcing the relevance of the evaluation to prevent elderly from falling.

\section{References}

1. Pinho TAM, Gurgel SN, Ferreira OGL, Bezerra VP, Moreira MASP. Concepções sobre envelhecimento e quedas para os idosos. FIEP Bulletin, Special Edition [internet], 2012 [cited 2015 Sep 22]; 82. Available from: http://www.fiepbulletin.net/index.php/ fiepbulletin/article/viewFile/2399/4494.

2. Bizerra CDA, Gonçalves RF, Carmo AFS, Mendes RNC, Moura LA. Quedas em idosos: identificação de fatores de risco extrínsecos em domicílios. J. res.: fundam. care. [internet]. 2014 [cited 2015 Sep 22]; 6(1): 203-212. DOI: http://dx.doi.org/10.9789/21755361.2014v6n1p203.

3. Gasparotto LPR, Falsarella GR, Coimbra AMV. As quedas no cenário da velhice: conceitos básicos e atualidades da pesquisa em saúde. Rev Bras Geriat Gerontol. [internet], 2014 [cited 2015 Sep 24]; 17(1): 201-209. Available from: http://www.scielo.br/ pdf/rbgg/v17n1/1809-9823-rbgg-17-01-00201.pdf.

4. Soares WJS, Moraes SA, Ferriolli E, Perracini MR. Fatores associados a quedas e quedas recorrentes em idosos: estudo de base populacional. Rev Bras Geriat Gerontol. [internet], 2014 [cited 2015 Sep 28]; 17(1): 49-60. Available from: http://www. scielo.br/pdf/rbgg/v17n1/1809-9823-rbgg-17-01-00049.pdf. 
5. Cruz DT, Ribeiro LC, Vieira MT, Teixeira MTB, Bastos RR, Leite ICG. Prevalência de quedas e fatores associados em idosos. Rev Saúde Pública. Online. [internet], 2012 [cited 2015 Oct 04]; 46(1): 138-146. DOI: http://dx.doi.org/10.1590/S003489102011005000087

6. Moreira MA, Oliveira BS, Moura KQ, Tapajós DM, Maciel ACC. A velocidade da marcha pode identificar idosos com medo de cair?. Rev Bras Geriat Gerontol. [internet], 2013 [cited 2015 Oct 04]; 16(1): 71-80. DOI: http://dx.doi.org/10.1590/ S1809-98232013000100008.

7. Abreu HCA, Reiners AAO, Azevedo RCS, Silva AMC, Abreu DROM, Oliveira AD. Incidência e fatores preditores de quedas de idosos hospitalizados. Rev Saúde Pública. Online. [internet], 2015 [cited 2015 Nov 15]; 49(37): 1-9. DOI: http://dx.doi. org/10.1590/S0034-8910.2015049005549.

8. Costa AGS, Araujo TE, Oliveira ARS, Morais HCC, Silva VM, Lopes MVO. Fatores de risco para quedas em idosos. Rev Rene. [internet], 2013 [cited 2015 Oct 15]; 14(4): 821-8. Available from: http://www.revistarene.ufc.br/revista/index. php/revista/article/view/1312/pdf

9. Ministério da Saúde (BR). Secretaria de Atenção à Saúde. Departamento de Atenção Básica. Envelhecimento e saúde da pessoa idosa. Série A Normas e Manuais Técnicos, Cadernos de Atenção Básica n. 19. Brasília: Ministério da Saúde; 2007 [cited 2015 Oct 15]. Available from: http://189.28.128.100/dab/docs/ publicacoes/cadernos ab/abcad19.pdf.

10. Gomes GS. Tradução, adaptação transcultural e exame das propriedades de medida da escala "Performance-Oriented Mobility Assessment" (POMA) para uma amostra de idosos brasileiros institucionalizados [dissertação]. Campinas (SP): Universidade Estadual De Campinas; 2003.

11. Oliveira KGF, Becerra LA, Santos AS, Dias LC, Lopes TS, Carvalho ESS. Prevalência de Fatores de Risco de Queda em Idosos Institucionalizados do Município de Cachoeira. Rev Bras Saúde Funcional. [internet], 2014 [cited 2015 Sep 16]; 2(2): 44-51. Available from: http://www.seer-adventista.com.br/ojs/index. php/RBSF/article/view/517/453.

12. Karuka AH, Silva JAM, Navega MT. Análise da concordância entre instrumentos de avaliação do equilíbrio corporal em idosos. Rev Bras Fisioter. [internet], 2011 [cited 2015 Sep 20]; 15(6): 460-6. DOI: http://dx.doi.org/10.1590/S1413-35552011000600006.

13. Sarmento WE, Sobreira FMM, Oliveira, AMB. Avaliação do equilíbrio e da mobilidade de idosos após um programa de Escola de Posturas. R Bras Ci Saúde. [internet] 2014 [cited 2015 Sep 20]; 18(1): 27-32. Available from: http://periodicos.ufpb.br/ ojs/index.php/rbcs/article/view/13763/11714.

14. Ministério da Saúde (BR). Resolução n 466/12 de outubro de 1996. Dispõe sobre diretrizes e normas regulamentadoras de pesquisa com seres humanos. Brasília (DF): Conselho Nacional de Saúde. [internet] 2012 [cited 2015 Aug 12]. Available from: http://www.sap.sp.gov.br/download_files/pdf_files/comite_de_ etica_em_pesquisa_SAP/resolucao-466_12-12.pdf.
15. Paula AFM, Ribeiro LHM, D'Elboux MJ, Guariento ME. Avaliação da capacidade funcional, cognição e sintomatologia depressiva em idosos atendidos em ambulatório de Geriatria. Rev Bras Clin Med. [internet], 2013 [cited 2015 Sep 20]; 11(3):2128. Available from: http://files.bvs.br/upload/S/1679-1010/2013/ v11n3/a3767.pdf.

16. Vinholes DB, Pacheco HA. Perfil do risco cardiovascular de pacientes diabéticos atendidos em ambulatório de especialidades. Rev Ciênc \& Saúde. [internet], Porto Alegre. 2014 [cited 2015 Sep 21]; 7(3): 116-122. Available from: http://revistaseletronicas.pucrs.br/ojs/index.php/faenfi/article/ view/17263/12496

17. Santos JS, Valente JM, Carvalho MA, Galvão KM, Kasse CA. Identificação dos fatores de riscos de quedas em idosos e sua prevenção. Rev Equilíbrio Corporal Saúde. [internet], 2013 [cited 2015 Sep 21]; 5(2): 53-59. Available from: http://pgsskroton. com.br/seer/index.php/reces/article/view/13/13.

18. Sturnieks DL, Menant J, Delbaere K, Vanrenterghem J, Rogers MW, Fitzpatrick RC, et al. Force-Controlled Balance Perturbations Associated with Falls in Older People: A Prospective Cohort Study. PLoSONE. on line. [internet] 2013 [cited 2015 Sep 20]; 8(8): 1-7. DOI: 10.1371/journal.pone.0070981.

19. Philip SA, Sengupta P, Benjamin Al. Prevalence of Falls and Fall Risk Assessment in an Urban Elderly Population of Ludhiana. Indian Journal of Gerontology. 2015; 29(2): 187-197.

20. Cavalcante ALP, Aguiar JB, Gurgel LA. Fatores associados a quedas em idosos residentes em um bairro de Fortaleza, Ceará. Rev Bras Geriatr Gerontol. [internet], 2012 [cited 2015 Sep 16]; 15(1): 137-46. DOI: http://dx.doi.org/10.1590/S180998232012000100015 .

21. Gutta S, Joseph A, Chakraborty A, Alexander AM. Study on the knowledge, attitudes and practices regarding prevention of recurrent falls in the elderly. IOSR Journal of Dental and Medical Sciences. [internet], 2013 [cited 2015 Sep 16]; 9(3): 32-38. Available from: http://www.iosrjournals.org/iosr-jdms/ papers/Vol9-issue3/G0933238.pdf?id=4528.

22. Al-Aama T. Falls in the elderly: spectrum and prevention. Can Fam Physician. [internet], 2011 [cited 2015 Sep 25]; 57(7): 771-6. Available from: http://www.cfp.ca/content/57/7/771.full. pdf+html.

23. Lima DA, Cezario VOB. Quedas em idosos e comorbidades clínicas. Revista HUPE. [internet], Rio de Janeiro. 2014 [cited 2015 Sep 16]; 13(2): 30-37. Availablefrom: http://revista.hupe. ueri.br/detalhe artigo. asp?id=469.

24. Antes DL, Schneider IJC, Benedetti TRB, D'Orsi E. Medo de queda recorrente e fatores associados em idosos de Florianópolis, Santa Catarina, Brasil. Cad. Saúde Pública. [internet], Rio de Janeiro. 2013 [cited 2015 Sep 16]; 29(4): 758-768. DOI: http://dx.doi.org/10.1590/S0102-311X2013000400013.

25. Rodrigues IG, Fraga GP, Barros MBA. Quedas em idosos: fatores associados em estudo de base populacional. Rev bras epidemiol. [internet], 2014 [cited 2015 Sep 26]; jul-set, 705-718. Available from: http://www.scielosp.org/pdf/rbepid/v17n3/ pt_1415-790X-rbepid-17-03-00705.pdf 
26. Pereira AA, Ceolim MF, Neri AL. Association between insomnia symptoms, daytime napping, and falls in community-dwelling elderly. Cad Saúde Pública. [internet], 2013 [cited 2015 Oct 23]; 29(3): 535-46. DOI: http://dx.doi.org/10.1590/S0102$311 \times 2013000700011$

27. Cavalcante DPM, Silva L de J da, Matos N, Borges I, Araújo DP, Pinheiro HA. Perfil e ambiente de idosos vítimas de quedas atendidos em um ambulatório de Geriatria e Gerontologia no Distrito Federal. Rev Kairós Gerontologia. [internet], 2015 [cited 2015 Oct 01]; 18(1): 93-107. Available from: http://revistas. pucsp.br/index.php/kairos/article/view/23890/17135.

28. Tanaka B, Sakuma M, Ohtani M, Toshiro J, Matsumura T, Morimoto T. Incidence and risk factors of hospital falls on longterm care wards in Japan. J Eval Clin Pract. [internet], 2012 [cited 2015 Sep 26]; 18(3): 572-7. Available from: http://onlinelibrary. wiley.com/doi/10.1111/j.1365-2753.2010.01629.x/pdf

29. Malini FM, Lopes CS, Lourenço RA. Medo de quedas em idosos: uma revisão da literatura. Revista HUPE. [internet], Rio de Janeiro. 2014 [cited 2015 Sep 25]; 13(2): 38-44. Available from: http://revista.hupe.uerj.br/detalhe artigo.asp?id=470

30. Silva JAMG, Módolo RM, Faganello FR. Equilíbrio funcional em indivíduos com doença de Parkinson e sua relação com a qualidade de vida. Ter Man. [internet], 2011 [cited 2015 Oct 01]; 9(43): 225-230. Available from: http://repositorio.unesp. br/bitstream/handle/11449/114975/ISSN16775937-2011-09-43225-230.pdf?sequence=1

31. Cocco AR, Naspolini AP, Grando FP, Volgoi N, Silva E, Medeiros PA, et al. A imobilidade em Instituição de Longa Permanência: Compreendendo o desafio vivenciado pelas equipes de saúde. Rev Kairós Gerontologia. [internet], 2013 [cited 2015 Sep 26]; 16(3): 263-284. Available from: http://revistas.pucsp.br/index. php/kairos/article/view/18551/13737

32. Chianca TCM, Andrade CR, Albuquerque J, Wenceslau LCC, Tadeu LFR, Macieira TGR, et al. Prevalência de quedas em idosos cadastrados em um centro de saúde de Belo Horizonte, Minas Gerais. Rev Bras Enferm. [internet], 2013 [cited 2015 Sep 23]; 2(66): 234-40. DOI: http://dx.doi.org/10.1590/S003471672013000200013

33. Vieira AAU, Aprile MR, Paulino CA. Exercício Físico, Envelhecimento e Quedas em Idosos: Revisão Narrativa. Rev. Equilíbrio Corporal Saúde. [internet], 2014 [cited 2015 Sep 28]; 6(1): 23-31. Available from: http://pgsskroton.com.br/seer/index. php/reces/article/view/6/6

34. Alves LV, Taguchi CK, Oliveira IL, Sousa MGC. Avaliação da tendência à quedas em idosos de Sergipe. Rev CEFAC. [internet], 2014 [cited 2015 Oct 18]; 16(5): 1389-1396. Available from: http://www.scielo.br/pdf/rcefac/v16n5/19820216-rcefac-16-05-01389.pdf

35. Ferreira LL, Sanches GGA, Marcondes LP, Saad PCB. Risco de queda em idosos institucionalizados com doença de Alzheimer. Rev Kairós Gerontologia. [internet]. 2013 [cited 2015 Oct 18]; 16(5): 95-105. Available from: http://www. fisioterapiaesaudefuncional.ufc.br/index.php/fisioterapia/ article/view/311/pdf_1
36. Gervásio FM, Barbosa A de $M$, Brandão $M$, Gonçalves CS, Ribeiro DM, Teixeira Junior JA da S, et al. Marcha de Idosas e Risco de Quedas. Rev Movimenta. [internet], 2012 [cited 2015 Oct 20]; 5(1): 40-54. Available from: http://repositorio.unb.br/ bitstream/10482/11625/1/ARTIGO MarchaldosasRisco.pdf

37. Santana JCS, Sauaia BA, Soares KVBC. O perfil postural do idoso asilado e sua relação com o nível de equilíbrio postural. Rev Pesq Saúde. 2011 [cited 2015 Sep 16]; 12(2): 9-12. Available from: http://www.periodicoseletronicos.ufma.br/ index.php/revistahuufma/article/view/1041/676

38. Aguiar CF, Assis M. Perfil de mulheres idosas segundo a ocorrência de quedas: estudo de demanda no Núcleo de Atenção ao Idoso da UnATI/UERJ. Rev Bras Geriatr Gerontol. [internet], 2009 [cited 2015 Sep 16]; 12(3): 391-404. Available from: http://www.observatorionacionaldoidoso. fiocruz.br/biblioteca/ artigos/147.pdf

39. Neves LO, Onishi ET, Peluzo E de ETP. Atuação do enfermeiro na estratégia saúde da família em relação aos idosos com vestibulopatias. Rev Equilíbrio Corporal Saúde. [internet], 2012 [cited 2015 Oct 01]; 4(1): 9-18. Available from: http://pgsskroton. com.br/seer/index.php/reces/article/view/37/38.

40. Granacher U, Gollhofer A, Hortobágyi T, Kressig RW, Muehlbauer T. The importance of trunk muscle strength for balance, functional performance, and fall prevention in seniors: a systematic review. Sports Med. [internet], 2013 [cited 2015 Oct 20]; 43(7): 627-41. Available from: http://link.springer.com/ article/10.1007\%2Fs40279-013-0041-1

\section{Publish in International Archives of Medicine}

International Archives of Medicine is an open access journal publishing articles encompassing all aspects of medical science and clinical practice. IAM is considered a megajournal with independent sections on all areas of medicine. IAM is a really international journal with authors and board members from all around the world. The journal is widely indexed and classified Q1 in category Medicine. 